\title{
Form of Rejection \\ in Buying and Selling Transactions in North Toraja (Sociolinguistic Review)
}

\author{
Anastasia Baan ${ }^{1 *}$, Roni La’biran ${ }^{2}$ \\ 1,2 Torja Christian University of Indonesia \\ * Corresponden author. Email: Anastasiabaan@ukitoraja.ac.id
}

\begin{abstract}
This research aims to describe the form of rejection language in buying and selling transactions in North Toraja. This research is qualitative. Data in the form of conversational parts of rejection language obtained from buying and selling transactions in North Toraja. Data is collected with (1) observation techniques, (2) record techniques, and (3) recording techniques. The results showed that the form of rejection language in buying and selling transactions in Bolu Market is: (1) rejection by using the word no or its equivalent is not, ndak, tae, eda and Jangan, (2) Rejection by using reason, (3) rejection using terms and conditions, (4) rejection by using proposals or choices that are constructive because it provides an alternative for the virgin, (5) rejection by using thank you, (6) rejection by adoring the goods, and (7) rejection by using nonverbal cues such as head shakes, silence, and hand signals.
\end{abstract}

Keywords: Form of Rejection, Buying and Selling Transactions, Sociolinguistics

\section{INTRODUCTION}

Sociolinguistic etymology comes from the words socio and linguistic. Socio(logi) is the same as the word social i.e. related to society while linguistics is related to language. Chaer and Agustina [1] state that sociolinguistics is a branch of linguistics that is interdisciplinary to the science of sociology, with the object of research the relationship between language and social factors in a speech society. Furthermore, Nababan in Chaer and Agustina, [1]) suggests that the study of language with a societal dimension is called sociolinguistic.

This definition indicates a relationship between language and society. Language is an arbitrary soundsymbol system, used by members of the public as a means of communication and interaction. In a sociolinguistic view, language is not only seen as an individual symptom but also a social symptom. As a social symptom, language and its use are determined by linguistic and nonlinguistic factors. Nonlinguistic factors are social factors: social status, education level, age, economic level, gender, etc., and situational factors: who speaks what language, to whom, when, where, and on what issues.
One form of the use of language by the community is seen in buying and selling transactions that occur in the market. Not infrequently we find rejection, both from sellers and buyers. According to Vanderveken in Nadar [4] Idolization is one form of speech. Furthermore, according to Brown and Levinson in Nadar, [4] rejection can be classified as an action that can threaten the negative face and positive face of the speech opponent, in connection with it, for rejection to be considered a polite rejection, certain strategies must be used, both negative politeness strategies and positive politeness strategies.

\section{METHODOLOGY}

This research is qualitatively descriptive [2]. Data obtained in the North Toraja region is in Bolu Market. Data collected with (1) observation techniques, namely observing the use of rejection in buying and selling transactions in the North Toraja Bolu market, (2) recording the use of rejection in buying and selling transactions in the North Toraja Bolu market, (3) recording techniques, namely the use of rejection in buying and selling transactions in the North Toraja Bolu market [3]. 


\section{ANALYSIS}

Forms of rejection in buying and selling transactions in the North Toraja Bolu market are displayed below:

1. Rejection by Using the Word No or Its Equivalent Does Not, Ndak, and do not

Rejection by using the word no or its equivalent is not, not, and cannot be seen in the following data:

Buyer : may I buy this sarung eighty thousand rupiahs uncle?

Seller: it can not

Speech occurs between speakers and speech partners in Bolu Market, the speech begins to type speakers are bidding on the price of sarung but rejected by speech partners. Data (3) is a form of rejection by using the word no, while the factor that influences rejection is that speakers reject the request of speech partners to lower the price of sarung

\section{Rejection by Using Excuses}

Rejection by using a base can be seen in the following data

Rejection using reason can be seen in the following data:

Buyer : Eighty-five thousand rupiahs this

bowl?

Seller : A hundred thousand rupiahs, because the bowl made of stencil

Speech occurs between speakers and speech partners in Bolu Market, the speech begins when speakers are bidding on the price of a bowl but are rejected by speech partners. The data is a form of rejection using reason, while the factor that influences rejection is that speakers reject the request of speech partners to lower their price. The reason is that the bowl material is made of stencil material.

\section{Rejection by Using Terms and Conditions}

Refusal using terms and conditions can be seen in the following data.

Buyer : Fifty thousand please, The right price sir

Seller : Please bargain first brother, the price depends on the same brand and material.

Just bargain brother the price depends on the brand and material)

Speech occurs between speakers and speech partners in Bolu Market, the speech begins when speakers bid on bag prices but are rejected by speech partners. The data is a form of rejection by using terms and conditions, while the factor that influences rejection is that speakers refuse the request of speech partners to lower the price by using the terms and conditions to buy bags in accordance with the price given by the speaker.

4. Rejection by Using invitor of speech or Choices That Are Constructive Because It Provides Alternatives for The invitor of speech

Rejection by using invitor speech as follow:

Buyer : A thousand these shoes please

Seller : Right Price please, it is cheap

Speech occurs between speakers and speech partners in Bolu Market, the speech begins when speakers bid on the price of shoes but are rejected by speech partners. The data is a form of rejection by using choice, while the factor that influences rejection is that the speaker rejects the request of the speech partner to lower the price by providing an alternative. The alternative is to offer the other item.

\section{Rejection by Using Thank You}

Rejection by using thank you can be seen in the following data.

Buyer : five thousand rupias please for two vegetable ties

Seller : Thank you madam, one vegetable ties will be ok

Speech occurs between speakers and speech partners in Bolu Market, the speech begins when speakers bid on vegetable prices but are rejected by speech partners. The data is a form of rejection by using thank you, while the factor that influences rejection is that the speaker rejects the request of the speech partner to lower the price by saying thank you.

\section{Rejection by Worshiping His Goods}

Rejection by worshiping his goods can be explained as follow:

Buyer : Two thousand rupias these shoes madam

Seller : These shoes made by good materials brother; I will give you if you pay three thousand rupias.

Speech occurs between speakers and speech partners in Bolu Market, the speech begins when speakers bid on the price of shoes but are rejected by speech partners. The data is a form of rejection by adoring the goods, while the factor that influences rejection is that speakers refuse the request of speech partners to lower the price by saying comments that the shoes are good material. 


\section{Rejection by Using Nonverbal Cues}

The use of nonverbal cues or rejection by shaking your head, silence, and hand gestures as a form of rejection can be seen in the following data.

Buyer : Ten Thousand Rupias for a kilogram of tomatoes?

Seller : Shaking his head

Speech occurs between speakers and speech partners in Bolu Market, the speech begins when speakers bid on the price of tomatoes but are rejected by speech partners. The data is a form of rejection using nonverbal cues, while the factor that influences rejection is that the speaker rejects the request of the speech partner to lower the price by shaking his head.

\section{CONCLUSION}

Based on the above exposure it can be concluded that the form of rejection language in buying and selling transactions in Bolu Market is: (1) rejection by using the word no or its equivalent is not, ndak, tae, eda and do not, (2) Rejection by using reason, (3) rejection using terms and conditions, (4) rejection by using proposals or choices that are constructive because it provides an alternative for the virgin, (5) rejection by using thank you, (6) rejection by adoring the goods, and (7) rejection by using nonverbal cues such as head shakes, silence, and hand signals.

\section{ACKNOWLEDGMENTS}

The researchers would like to express all the people who participated in the research, special thanks to local government of Tana Toraja and Toraja Utara who have been given us support through research permission in their government area.

\section{REFERENCES}

[1] Chaer, Abdul dan Leonie Agustina. 2010. "Sosiolinguistik Perkenalan Awal". Jakarta: Rineka Cipt

[2] Mahsun. (2005). Metode Penelitian Bahasa. Jakarta : Raja Grafindo Persada

[3] Arikunto, Suharsimi. (2006). Prosedur Penelitian Suatu Pendekatan Praktik, Jakarta: Rineka Cipta

[4] Nadar F.X, Putu Wijana, dkk. 2005. "Penolakan Dalam Bahasa Inggris Dan Bahasa Indonesia". Jurnal Penelitian Humaniora, Vol 17. 